\title{
Palavras da Editora
}

Este novo número da Revista História Oral dá continuidade à orientação seguida ao longo de sua trajetória de construir um espaço plural que incorpore a diversidade e procure estimular o diálogo entre os diferentes usos da História Oral. Dentro dessas linhas que norteiam as preocupações da Associação Brasileira de História Oral, reafirma-se a necessidade de incorporação de novos espaços de debate e temas, bem como o compromisso de reforçar a idéia da História Oral como um instrumento a mais para aprimorar a qualidade acadêmica e a interpretação científica. Assim, a utilização da História Oral pressupõe pesquisa, método, análise crítica e reflexão sobre o material obtido através das entrevistas orais.

De acordo com estas perspectivas, o número - de responsabilidade do novo comitê editorial escolhido no VIII Encontro Nacional de História Oral, realizado no Acre em 2006 - foi dividido em três eixos temáticos.

O primeiro eixo é composto pelo dossiê "Amazônia" que contém três artigos. Raymundo Maués discute lendas e mitos sobre o boto na Amazônia enfatizando seus aspectos simbólicos. Regina Beatriz Guimarães Neto reflete sobre a História das cidades no noroeste de Mato Grosso, dando especial atenção aos trabalhadores rurais e suas lutas pela posse da terra. Carla Monteiro de Souza discute os processos de imigração e povoamento do estado de Roraima estabelecendo como foco as estratégias e relações de identidade entre diferentes grupos diante de uma nova realidade.

O segundo eixo apresenta um artigo de Alessandro Portelli, que trata das ambigüidades das memórias sobre o pós-guerra em Roma, e o texto de Marco Aurélio Santana, que analisa as formas pelas quais militantes dos movimentos sindicais constroem suas memórias acerca das mobilizações experimentadas em Volta Redonda.

O terceiro eixo temático privilegia o uso de História Oral como instrumento para recuperação de memórias sobre práticas de ensino e saberes. $\mathrm{O}$ artigo de Isabel Cristina Martins Guillen apresenta a trajetória 
de um "mestre" cantador de Pernambuco e seu papel como transmissor de uma cultura popular. O artigo de Selva Guimarães explora o uso da História Oral como instrumento pedagógico para o ensino de História enquanto disciplina escolar.

Este número traz ainda as contribuições de Paulo Knauss e Ana Mauad sobre as experiências de pesquisa e constituição de acervo do Laboratório de História Oral e Iconografia (LABHOI) da Universidade Federal Fluminense e uma resenha de Alice Lang sobre o livro Augusto e Léa de autoria de José Carlos Sebe bom Meihy.

Marieta de Moraes Ferreira

Julho de 2007 